Renata Śliwa, Renata Żaba-NIErodA'

\title{
Ocena skutków regulacji jako element procesu regulacyjnego
}

\section{Wprowadzenie}

Teoretycznie regulacje są efektem niedoskonałości działania mechanizmu rynkowego, objawiających się istnieniem monopoli, ujawnianiem się efektów zewnętrznych czy występowaniem niedoskonałości informacyjnej². Mimo swojej dynamiki i zdolności do samoregulacji rynek pozostawia ważne obszary życia społecznego bez pożądanych społecznie efektów, dostarcza silne bodźce do działań podmiotów prywatnych, które pozostają w istotnej sprzeczności z ich efektywnością społeczną czy ekologiczną.

Ekonomiczne funkcje państwa (alokacyjna, stabilizacyjna, redystrybucyjna) tworzą pewną platformę teoretyczną, uzasadniającą obecność państwa $\mathrm{w}$ gospodarce, $\mathrm{w}$ tym $\mathrm{w}$ postaci regulacji.

Regulacje stanowią odpowiedź państwa na pojawiające się niebezpieczeństwa i związane z nimi ryzyko. Ochrona wartości o charakterze publicznym, uznanych w społeczeństwie za ważne, jak również występowanie nieefektywności rynku ukazują regulacyjne interwencje państwa jako działania pożądane. Społeczeństwa wykazują silną potrzebę pewnych dóbr publicznych, szczególnie tych gwarantujących określony poziom bezpieczeństwa i wzrost dobrobytu.

Gdyby regulację uznać za działania z zakresu aktywności organów publicznych nakierowanych na wykorzystanie instrumentów polityki gospodarczej w celu tworzenia przestrzeni administracyjnoprawnej kształtującej pewne postawy podmiotów gospodarczych (stymulowanie i hamowanie zachowań przedsiębiorstw i konsumentów) i zawęzić je do regulacji ekonomicznej (a nie pojętej szeroko społeczno-ekonomicznej), wówczas jej przedmiotem będzie koncentracja na ograniczeniach zawodności rynku (szczególnie monopolizacji sił rynkowych) oraz na podnoszeniu efektywności ekonomicznej poprzez promowanie i ochronę konkurencji.

1 Dr Renata Śliwa, Uniwersytet Pedagogiczny im. KEN w Krakowie, dr Renata Żaba-Nieroda, Uniwersytet Ekonomiczny w Krakowie.

2 J.E. Stiglitz, Freefall. Free markets and the sinking of the global economy, London 2010; J.E. Stiglitz, Ekonomia sektora publicznego, Warszawa 2015, s. 90. 
Ekonomiczne skutki regulacji sprowadzają się ogólnie do zjawiska internalizacji efektu, będącego uprzednio efektem zewnętrznym (np. podnoszenie kosztu działania wcześniej prywatnie darmowego, ale obarczającego społeczeństwo wysoką ceną). Koszty regulacji ponoszą po części różne grupy podmiotów gospodarczych: przedsiębiorstwa w postaci wzrostu kosztów produkcji, właściciele czynników produkcji w postaci spadku wykorzystania czynników produkcji czy konsumenci w postaci wzrostu cen. Większość korzyści ma uzyskać społeczeństwo jako całość, niekoniecznie indywidualne podmioty gospodarcze, które bezpośrednio ponoszą koszty tych regulacji.

Efektywność (użyteczność) regulacji jest trudna do oszacowania. Ogólna zasada przyjęta przez ekonomistów sprowadza się do oceny podejmowanej regulacji w zależności od stopnia trudności jej egzekwowania. Monitorowanie skutków regulacji ex post, jak również wskazanie ex ante na możliwe jej konsekwencje jest ściśle związane m.in. z oszacowaniem stopnia skomplikowania w jej egzekwowaniu, szczególnie jednak na ustalenie kosztów i korzyści z jej wprowadzania.

Jednym $\mathrm{z}$ istotnych podejść metodycznych do oceny regulacji jest ocena wpływu (ang. impact assessment), w ramach której dominuje metoda RIA (ang. Regulatory Impact Assessment), po polsku OSR (ocena skutków regulacji). Duży potencjał zabiegów związanych z tą oceną sprowadza się głównie do usprawnienia dialogu między organami publicznymi a interesariuszami, tworząc w ten sposób grunt pod wyższą jakość debaty, instytucji i w efekcie uchwalanego prawa. Zabiegi prowadzone w ramach OSR w celu neutralizowania negatywnych skutków działania mechanizmu rynkowego postrzegane są jednocześnie jako przejaw lepszego rządzenia (ang. better governance), nastawionego w szczególności na podniesienie poziomu inkluzyjności społecznej/obywatelskiej. Stosowanie OSR usprawnia proces stanowienia prawa, które kształtuje ostateczną regulację. Ocena skutków regulacji promuje szczególnie aspekt systemowości czy podejście porównawcze w polityce decyzyjnej. Narzuca potrzebę wyraźnego wyodrębnienia problemu, który jest przedmiotem regulacji, szczegółowych celów politycznych, jakie mają być osiągnięte, oraz wskazania alternatywnych sposobów ich osiągania.

Celem artykułu jest ukazanie OSR jako ważnego filara stanowienia prawa, na którym bazują regulacje. Podstawowe pytanie badawcze brzmi: czy procedura OSR ma potencjał prawno-administracyjny w realizacji celu, jakim jest podniesienie efektywności regulacyjnej ${ }^{3}$ ?

U podstaw rozważań leży hipoteza, że OSR może mieć pozytywny wpływ na staranność, wiarygodność, przejrzystość i skuteczność procesu regulacji.

3 Zob. R. Śliwa, Przyczynek do badań na temat efektywności regulacji sektora telekomunikacyjnego, „Telekomunikacja i Techniki Informacyjne” 2015, nr 1-2. 
Przyjęta struktura opracowania bezpośrednio służy realizacji celu artykułu. Obejmuje ona trzy zasadnicze części. W pierwszej zaprezentowane zostały teoretyczne podwaliny funkcjonowania strefy regulacji w przestrzeni społeczno-gospodarczej ze wskazaniem na znaczenie oceny skutków regulacji w tym obszarze. W drugiej części ukazano istotę oraz etapy przeprowadzania oceny wpływu. Publikacje kończą przykłady polskiej specyfiki wdrażania i rozwijania oceny skutków regulacji z naciskiem na najważniejsze bariery jej aplikowania w proces tworzenia prawa w naszym kraju.

\section{Rola oceny wpływu regulacji w procesie kształtowania życia społeczno-gospodarczego}

Regulacje stanowią domenę działalności władz publicznych, w ramach których podejmowane decyzje mają odzwierciedlać wypracowane wartości społeczne i gospodarcze dopasowane do poszczególnych przypadków regulacji. Reprezentują one obszar decyzji władz publicznych, gdzie doktrynalne podejście nie ma racji bytu, a obywatele mają prawo oczekiwać dążenia do maksymalizacji pragmatyzmu ze strony regulujących. Na procesy prowadzące do wdrażania regulacji oddziałują silnie czynniki ideologiczne, których siła tkwi głównie w naturalnej dynamice przemian systemowych kapitalizmu (zanikanie potrzeby jednych regulacji, pojawianie się konieczności wprowadzania innych) hamowanej często przez grupy partykularnych interesów.

W nauce kładzie się nacisk na brak „ogólnej reguły sprzyjającej lub sprzeciwiającej się regulacji”" Każda regulacja wymaga analizy kontekstu społeczno-gospodarczego w celu wyeliminowania projekcji regulacji przynoszących więcej kosztów niż korzyści czy dbałość jedynie o interes prywatny. Regulacje przyczyniają się do powstawania relacji sektora publicznego ze społeczeństwem. W tym obszarze eksponowane są takie wartości publiczne jak: dobro wspólne z interesem publicznym i spójnością społeczną, altruizm $z$ dążeniem do gwarantowania godności ludzkiej, równoważenie rozwoju jako dbałość o interes społeczny przyszłych pokoleń, zapewnianie powagi systemu ze szczególnym uwzględnieniem jego stabilności wydobywanej z wartości pierwotnych takich jak reguła prawa, niedyskryminacji czy wiarygodności oraz stabilności i ciągłości. Ważnymi wartościami publicznymi są jednocześnie te scalające stosunki administracji publicznej ze sferą polityki, ukazujące odpowiedzialność za wykonywanie publicznej służby, wrażliwość społeczną, służebność i elastyczność wobec społeczeństwa, jak również lojalność polityczną jako fundamenty decyzji publicznych i ich efektów. Administracja publiczna, jako ważny podmiot i ogniwo w procesie regulacyjnym, buduje ważny obszar współpracy z sze-

4 J.K. Galbraith, Godne społeczeństwo. Program troski o ludzkość, Warszawa 1999, s. $70-71$. 
roko pojmowanym otoczeniem, a filarami tych konstrukcji decyzyjnych jest transparentność działań, rozumiana jako otwartość, ale i zabezpieczanie i utajnianie ważnych informacji, reagowanie na potrzeby, neutralność, balansowanie interesów różnych grup społecznych czy promowanie konkurencyjności i współpracy społecznej ${ }^{5}$. Wymienione wybrane wartości publiczne stanowią o jakości i rzetelności regulacji, a tym samym o ich wkładzie we wzrost dobrobytu społecznego.

Regulacje ekonomiczne w odniesieniu do ochrony konsumentów, zapewniania stabilności systemowej czy gwarantowania zaufania na rynku muszą spełniać test legalności, proporcjonalności do zakładanych celów regulacji i służyć interesowi publicznemu. Reguła proporcjonalności w największej mierze łączy prawne i ekonomiczne uwarunkowania oceny działań regulacyjnych. Wyłania się tutaj konieczność zrównoważenia kosztów i korzyści niesionych przez przyjmowane regulacje. Jedynie ukazanie przewagi korzyści nad kosztami w teście proporcjonalności uzasadnia dążenie do implementowania regulacji ${ }^{6}$.

Regulacja, która może przybierać różne formy, wpływa na rozwój gospodarczy kraju poprzez neutralizowanie skutków istotnych zawodności rynku wynikających z korzyści skali czy korzyści zakresu, niedoskonałości informacji w transakcjach rynkowych, istnienia niekompletnych rynków, ujawniania się efektów zewnętrznych czy zniekształceń podziału dochodów i bogactwa. Jej rola ukazywana jest również w odniesieniu do dostaw ważnych społecznie usług generowanych w sektorach infrastrukturalnych ${ }^{7}$. Regulacje mają duży wpływ na wyniki gospodarcze poprzez kształtowanie klimatu dla inwestycji. Proces budowy instytucji w kontekście obniżania asymetrii informacyjnej, formowania odpowiednich bodźców ekonomicznych i redukowania kosztów transakcyjnych jest także postrzegany jako element reżimu regulacyjnego ${ }^{8}$.

Rozpoznanie regulacji jako ważnego stymulatora prorynkowych zabiegów umacniających rozwój społeczno-gospodarczy prowadzi w sposób nieunikniony do rozpatrywania ich efektywności i sprawności (osiągania zamierzonych celów przy najniższych możliwych kosztach - zarówno administracyjnych, jak i gospodarczych). Rodzi się więc pilna potrzeba systemowego szacowania wpływu istniejących i wprowadzanych regulacji na

5 T.B. Jørgensen, B. Bozeman, Public values: an inventory, „Administration and Society" 2007, vol. 39, no. 3, s. 360-366.

6 R. Nebel, Regulations as a source of systemic risk: the need for economic impact analysis, „The Geneva Papers on Risk and Insurance” 2004, vol. 29, no. 2, s. 274.

$7 \mathrm{H}$. Jalilian, C. Kirkpatrick, D. Parker, The impact of regulation on economic growth in developing countries: a cross-country analysis, "World Development” 2007, vol. 35, iss. 1, s. 87-103.

8 Ibidem. 
ekonomiczne, społeczne czy ekologiczne aspekty równoważonego rozwoju gospodarek ${ }^{9}$.

Zasadniczy problem ujawniający się $\mathrm{w}$ procesie oceny efektywności działań regulacyjnych sprowadza się głównie do trudności w kwantyfikowaniu i nadawaniu wartości pieniężnej świadczonym usługom (przedsiębiorstwa efektywność działania opierają na ilościowym ujęciu sprzedawanych produktów i usług oraz ich cenie) oraz prawnym ograniczaniu wolności działania (przedsiębiorstwa działają na bazie konstytucyjnie gwarantowanej wolności gospodarczej).

Ocena wpływu regulacji na potencjalne lub faktyczne zmiany społecznogospodarcze ma umożliwić rozpoznanie zarówno pozytywnych, jak i negatywnych stron obecności państwa w procesach społeczno-gospodarczych ${ }^{10}$. Planowane efekty pozytywne regulacji każdorazowo pociągają za sobą pewne koszty. Generowanie tych kosztów nie wiąże się z dyskwalifikacją regulacji, ale rodzi co najmniej konieczność jej zestawienia z korzyściami.

Praktykowanie procedur oceny skutków regulacji jest przejawem dążenia ku doskonaleniu procesu regulowania w świetle przystawania do zasad odpowiedzialności, transparentności czy spójności podejmowanych interwencji publicznych. Najwyraźniej eksponowane w literaturze przymioty ocen wpływu regulacji (w tym OSR) oraz zidentyfikowane kanały wpływu na gospodarkę zostały pokazane w tabeli 1 .

Narzędzie poprawy tworzenia prawa, jakim jest ocena skutków regulacji, cechujące się systemowością, lokalnością, wielostopniowością, transparentnością, odpowiedzialnością i spójnością wpływa na potencjalnie większą sprawność ingerencji państwa, udrożnienie kanałów informacyjnych między władzą publiczną a obywatelami oraz wyższą efektywność administrowania publicznego i całego systemu regulacyjnego.

Obraz zmian zastosowania OSR w systemach prawnych poszczególnych krajów skłania dodatkowo do przypisania temu narzędziu pozytywnych cech wymienianych $w$ tabeli 1 , oddziałujących potencjalnie na lepszy kształt procesu tworzenia prawa i regulacji. Największy wzrost liczby krajów wykorzystujących OSR odnotowano od połowy lat 90. XX w. do 2008 r. Okres ostatniego kryzysu gospodarczego wykazywał trend stabilny obejmujący słabe zmiany w liczbie krajów przyjmujących OSR. Od 2012 r. zarysowująca się zmiana skłania do twierdzenia o wzmacnianiu się trendu wzrostowego ${ }^{11}$.

9 C. Kirkpatrick, D. Parker, Regulatory Impact Assessment and regulatory governance in developing countries, „Public Administration and Development” 2004, vol. 24, no. 4, s. 334-335.

10 Więcej Regulatory Impact Analysis. Best practices in OECD countries, OECD, Paris 1997, s. 8.

11 Źródło: Measuring Regulatory Performance. 2014 Regulatory Indicators Survey results, http://www.oecd.org/gov/regulatory-policy/measuring-regulatory-performance.htm (dostęp: 1.07.2017). 


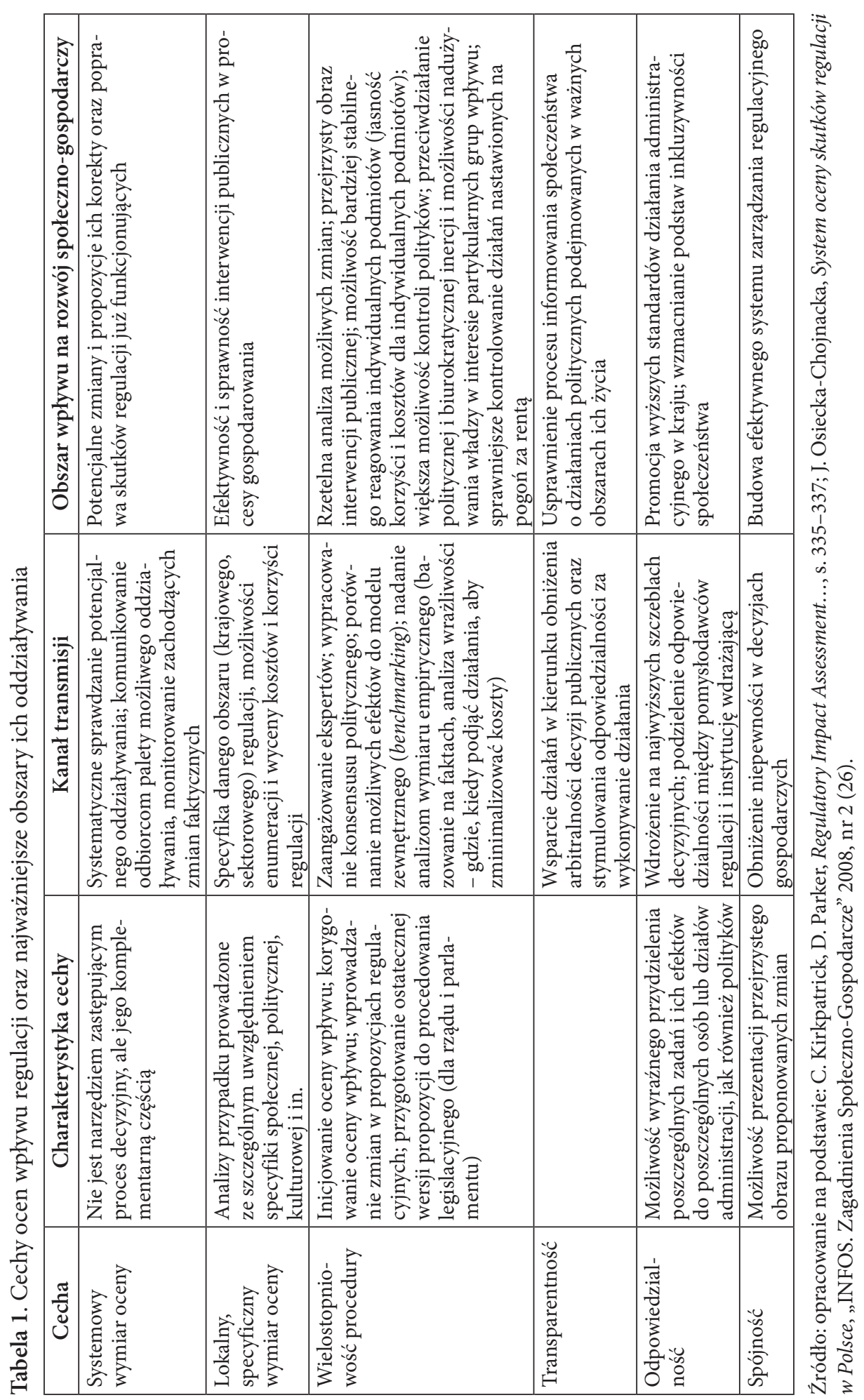




\section{Istota oraz etapy oceny wpływu decyzji regulacyjnych}

Ocena skutków regulacji jest kluczowym elementem programu poprawy jakości istniejącej i wprowadzanej regulacji czy szerzej polityki publicznej. Jest to metoda analityczna wspierająca polityków w procesie tworzenia prawa, a także metoda posiłkowa w projektowaniu, implementowaniu i monitorowaniu oczekiwanych efektów systemu regulacyjnego, formowanego metodycznie dla dostarczania wiedzy na temat możliwych konsekwencji proponowanych oraz faktycznych efektów istniejącej regulacji. Włączanie OSR w procesy regulacyjne jest przejawem dążenia ku wzmacnianiu znaczenia narzędzi decyzyjnych opartych na faktach. Podejście takie jest $\mathrm{z}$ kolei silnym stymulatorem dobrego rządzenia poprzez wzmacnianie transparentności i odpowiedzialności w politycznym decydowaniu ${ }^{12}$.

OECD - organizacja, która ma swój istotny wkład w wypracowywanie i opracowywanie dobrych praktyk i przewodników po metodyce OSR, ujmuje regulacje jako zróżnicowany zestaw instrumentów, za pomocą których rządzący formułują nakazy i zakazy dla przedsiębiorstw i obywateli ${ }^{13}$. Dlatego też OSR jawi się jako narzędzie pomocne w analizie wyboru lepszej polityki publicznej ${ }^{14}$.

Ocena skutków regulacji jest elementem procesu decyzyjnego, w ramach którego przyjmuje się decyzje jako efekt, po pierwsze, procesu gromadzenia informacji, po drugie, określenia relacji między celami a środkami, po trzecie, analizy przyszłych skutków przygotowywanego aktu prawnego (analiza prognostyczna warstwy decyzji) ${ }^{15}$.

W ramach zabiegów o lepsze regulacje (abg. better regulation) ocena skutków regulacji postrzegana jest jako najważniejsza innowacja ${ }^{16}$, nie tylko umożliwiająca ukazanie w przejrzysty sposób faktycznego problemu, ale także zidentyfikowanie alternatyw regulacyjnych oraz określenie ich kosztów i korzyści ze współudziałem wszystkich interesariuszy (konsultacje społeczne).

Innowacyjność OSR przejawia się w tym, że efektywnie zastępuje kontrolę ex-ante (poprzez budżetowanie), jak i ex-post (rozstrzygnięcia sądowe - sądowy przegląd reguł) i uaktywnia swój potencjał kontroli wówczas, gdy

12 C. Kirkpatrick, D. Parker, Regulatory Impact Assessment: an overview [w:] Regulatory Impact Assessment: towards better regulation, C. Kirkpatrick, D. Parker (eds.), The CRC Series on Competition, Regulation and Development, Edward Elgar Publishing 2007, s. 1.

13 The OECD report on regulatory reform: synthesis, OECD Paris 1997.

14 C. Kirkpatrick, D. Parker, Regulatory Impact Assessment: an overview..., s. 3.

15 E. Knosala, Zarys teorii decyzji w nauce administracji, Warszawa 2011, s. 97.

16 A. Renda, Impact assessment in the EU: the state of the art and the art of the state, Brussels 2006; J. Turnpenny, C.M. Radaelli, A. Jordan, K. Jacob, The policy and politics of policy appraisal: emerging trends and new directions, „Journal of European Public Policy" 2009, vol. 16 (4), s. 640-53. 
reguły są dopiero kształtowane. $\mathrm{W}$ wymiarze procedury administracyjnej OSR jest efektywna $w$ wielu aspektach. Umożliwia monitoring postępów $\mathrm{w}$ tworzeniu prawa przez dobrze zorganizowane grupy interesu i potencjalne wkroczenie z propozycjami zmian czy wstrzymania regulacji poprzez instytucje do tego powołane, tj. Office of Information and Regulatory Affairs (OIRA) w Stanach Zjednoczonych, Treasury Board Secretariat w Kanadzie, Better Regulation Executive and Regulatory Policy Committee w Wielkiej Brytanii ${ }^{17}$. Ocena skutków regulacji w swojej procedurze przewiduje możliwości zapoznania się z regulowanym problemem przez polityków i włączenie się $\mathrm{w}$ proces regulacji przed jego zakończeniem ${ }^{18}$, jest możliwym instrumentem przesunięcia siły działania od agencji publicznych do najsilniejszych grup interesu (elektoratu) ${ }^{19}$.

Celem OSR jest wyjaśnianie znaczenia składanych propozycji regulacyjnych, wyrastających z nich potencjalnego ryzyka oraz możliwych opcji realizacji zakreślonych celów ${ }^{20}$.

Metoda OSR przebiega w kilku etapach - ocena w fazie wstępnej nowej regulacji, po konsultacjach oraz końcowa ocena załączana do projektu zmiany legislacyjnej ${ }^{21}$. Każda faza procesu OSR obejmuje liczne zadania, takie jak opis problemu i celu propozycji regulacyjnej, opis opcji, zarówno regulacyjnych, jak i nieregulacyjnych, osiągania przyjętych celów, oszacowanie znaczących skutków - negatywnych i pozytywnych wpływów regulacji na konsumentów, przedsiębiorstwa i inne grupy interesu, konsultacje $\mathrm{z}$ interesariuszami, rekomendacja opcji z uzasadnieniem ich wyboru ${ }^{22}$.

Proces ewaluacji w ocenie wpływu może być prowadzony na kilku poziomach, w ramach których stosowane są właściwe na każdego z nich zestawy wskaźników. Raport oceny wpływu (IA) sprawdzany jest pod wzglę-

17 F. de Francesco, C.M. Radaelli, V.E. Troeger, Implementing regulatory innovations in Europe: the case of impact assessment, „Journal of European Public Policy” 2011, DOI:10.1080/13501763.2011.607342, s. 3-4.

18 M.D. McCubbins, R.G. Noll, B.R. Weingast, Structure and process, politics and policy: administrative arrangements and the political control of agencies, „Virginia Law Review" 1989, vol. 75 (2), s. 481.

19 M.D. McCubbins, R.G. Noll, B.R. Weingast, Administrative procedures as instruments of political control, „Journal of Law, Economics, and Organization” 1987, vol. 3 (2), s. 274 .

20 Better regulation: making good use of regulatory impact assessment, National Audit Office, Report by the Comptroller and Auditor General HC 329 Session 20012002, London 2002, s. 51.

21 C. Kirkpatrick, D. Parker, Regulatory impact assessment..., s. 336.

22 C. Kirkpatrick, D. Parker, Regulatory Impact Assessment: an overview..., s. 4; Ocena Wplywu Regulacji. Poradnik dla administracji publicznej, Warszawa 2015 (Poradnik przygotowany w ramach projektu „Ocena skutków regulacji oparta na dowodach. Model wykorzystania istniejących dowodów analityczno-ewaluacyjnych w procesie oceny społeczno-ekonomicznych efektów planowanych regulacji” realizowanego i finansowanego z Programu Innowacje Społeczne Narodowego Centrum Badań i Rozwoju). 
dem zgodności z procedurami, procesami, wymogami, miarami RIA/IA. Ewaluacja efektu oceny wpływu nie koncentruje się na formalnych wymogach, a zagłębia się w jakość podejmowanej analizy. Ocena efektów ewaluacji sprowadza się do pomiaru faktycznych efektów RIA w kategoriach jakości skutków regulacyjnych. Ewaluacja wpływu ocenia wpływ zmian w jakości regulacji na szersze ekonomiczne, społeczne i ekologiczne lub inne wyszczególnione cele ${ }^{23}$.

Próby wypracowania pewnych wspólnych ram działań na rzecz lepszej regulacji podejmowane przez Unię Europejską w ramach Europejskiej Sieci na Rzecz Reform Regulacji (European Network for Better Regulation) ${ }^{24}$ doprowadziły do ukształtowania ujęcia OSR jako „systematycznej, obowiązkowej i spójnej oceny korzyści i kosztów regulacji pod względem społecznym, gospodarczym i środowiskowym”. Wskazano również na najważniejsze cele OSR, które jednocześnie determinują funkcje tego narzędzia, tj. funkcja informacyjna w stosunku do interesariuszy, funkcja określenia zarysu ex ante oddziaływania zewnętrznego, funkcja ex post oszacowania trafności wcześniejszej oceny wpływu ${ }^{25}$.

Specyfika (lokalność) kulturowa, polityczna, legislacyjna, administracyjna czy sektorowa przyjętych regulacji minimalizuje możliwości całko-

23 D. Parker, (Regulatory) Impact assessment and better regulation [w:] D. Wright, P. de Hert, privacy impact assessment, law, governance and technology, Series 2012, no. 6, DOI 10.1007/978-94-007-2543-0_3.

24 Trzyletni projekt UE (FP6-CITIZENS) - zakończony w grudniu 2008 r., mający na celu powołanie do działania oraz animowanie europejskiej sieci, mającej udoskonalić i rozpowszechnić aktualną wiedzę o procesach regulacyjnych, jak również stopniu oraz formie implementacji procedur oceny wpływu w krajach członkowskich UE. W ramach sieci określono następujące zadania: 1. Zbudowanie w krajach członkowskich bazy danych o stanie rozwoju ocen wpływu (DIADEM). 2. Wykazywanie zależności między rodzajem oceny wpływu a różnymi wskaźnikami jakości regulacyjnej (np. zgodność z prawem, sprawność, efektywność, poparcie i zaangażowanie ze strony sektora prywatnego). 3. Upowszechnianie wiedzy na temat bieżącej metodologii stosowanej do oceny skutków regulacji i zrównoważenia oceny wpływu. 4. Zbieranie i popularyzowanie/dzielenie się wiedzą na temat dobrego stanowienia prawa w Europie na stronie internetowej www.enbr.org. 5. Kształtowanie interdyscyplinarnych studiów i analiz jako platform dzielenia się wiedzą i wypracowywania narzędzi dydaktycznych/ szkoleniowych. 6. Działania na rzecz uświadamiania znaczenia ocen wpływu w lepszym stanowieniu prawa i bardziej zrównoważonym rozwoju poprzez organizację warsztatów. 7. Publikacja rocznych raportów o postępach pracy nad implementacją ocen wpływu w krajach członkowskich, łącznie z sugestiami rozwiązań krajowych. 8. Wskazywanie na konieczność badań nad lepszym stanowieniem prawa z perspektywy interdyscyplinarnej. 9. Praca na rzecz tworzenia sieci wzmacniających harmonizacje procedur ocen wpływu w krajach członkowskich UE. 10. Podtrzymywanie dialogu z grupami roboczymi Komisji Europejskiej i Rady Europejskiej, ekspertami programu reform regulacyjnych OECD, http://cordis.europa.eu/project/rcn/78653_en.html (dostęp: 1.07.2017).

25 J. Osiecka-Chojnacka, System oceny skutków regulacji w Polsce, „INFOS. Zagadnienia Społeczno-Gospodarcze" 2008, nr 2 (26). 
witego przejmowania schematów analitycznych. Istnieje jednakże ogólny schemat procesu oceny wpływu regulacji na życie społeczne i gospodarcze. Pierwszy etap obejmuje zwykle identyfikację problemu i podjęcie decyzji, czy zidentyfikowany problem podlega regulacji czy innej formie pozaregulacyjnej reakcji. Następnie obowiązkowo prowadzone są konsultacje proponowanej regulacji ze wszystkimi zainteresowanymi stronami. Włączenie wszystkich stron do wyrażenia swojej opinii i prośba o przedłożenia sugestii upoważnia następnie do prac nad przygotowaniem wersji legislacyjnej regulacji, która musi odzwierciedlać oceny przedłożone przez zainteresowane regulacjami strony. Kolejny etap obejmuje ewaluację legislacyjnie procedowanej regulacji w celu sprawdzenia spójności z założonymi początkowo celami. Ostatni etap to działania monitorujące skutki wdrożonej już regulacji w kontekście generowanych przez nią zakładanych korzyści i ewentualnego ujawniania się nieoczekiwanych kosztów. Ten typ ewaluacji przeprowadzany jest cyklicznie w odniesieniu do danej regulacji ${ }^{26}$.

\section{Krytyczne ujęcie oceny skutków regulacji oraz zastosowanie tej metody w uwarunkowaniach regulacyjnych w Polsce}

Rzetelnie i systemowo prowadzona ocena wpływu (ocena skutków regulacji) ex ante ma duży potencjał minimalizacji ryzyka związanego $\mathrm{z}$ interwencją publiczną. Dodatkowo systemowy i przejrzysty charakter oceny wpływu ex post kryje w sobie siłę pozytywnego oddziaływania na proces pełniejszego zrozumienia powodzeń i porażek związanych z implementowanym prawem, a w ten sposób na poprawę działania samego instrumentu OSR, jak i systemu regulacyjnego gospodarki. Kluczową rolę ma tutaj również do odegrania aspekt powiązań OSR z doskonaleniem otoczenia regulacyjnego oraz powiązań otoczenia regulacyjnego z osiąganiem celów gospodarczych, społecznych i ekologicznych w ramach polityki rozwoju kraju ${ }^{27}$.

OSR pozwala oprzeć proces wypracowywania i przyjmowania aktów prawnych na dowodach i w ten sposób podnieść skuteczność i efektywność podejmowanych rozwiązań. Argumentacja stron oparta na racjonalnej procedurze negocjacyjnej, odwołująca się do zestawień i wniosków analitycznych oraz naukowych, operująca na założeniach i konkretnych źródłach danych sprawniej doprowadza do konsensusu, uwiarygadnia podejmowane wysiłki, a efekty prac legislacyjnych czyni bardziej trwałymi ${ }^{28}$.

26 C. Kirkpatrick, D. Parker, Regulatory Impact Assessment: an overview..., s. 8-11.

27 Ibidem, s. 10; więcej: Regulatory Impact Analysis, OECD resources, http://www. oecd.org/gov/regulatory-policy/ria.htm (dostęp: 1.07.2017).

28 Wytyczne do przeprowadzania oceny przewidywanych skutków społeczno-gospodarczych zgodnie z $\$ 24$ ust. 3 uchwały nr 190 Rady Ministrów z dnia 29 października 2013 r. - Regulamin pracy Rady Ministrów (teskt jedn.: Dz. U. z 2016 r. poz. 1006 ze zm.). 
Jako obszary procesu kształtowania OSR w systemie stanowienia prawa w Polsce, które wykazują największe słabości, zidentyfikowano ${ }^{29}$ :

- wprowadzenie jasnego kryterium podziału aktów prawnych poddawanych OSR ${ }^{30}$,

- możliwość pogłębienia oceny po stosownym zgłoszeniu wnioskodawcy i akceptacji organu koordynującego,

- umocnienie pozycji administracyjnoprawnej w procesie stanowienia prawa jednostki koordynującej OSR - kontrola, kształtowanie rozwiązań metodologicznych, możliwość blokowania projektu w przypadku niespełnienia standardów jakościowych,

- uświadamianie, mocne akcentowanie i faktyczne nadawanie odpowiedniego wymiaru strategicznej roli długookresowych celów państwa w ramach procesu oceny wpływu,

- włączanie grup społecznych szczególnie zainteresowanych skutkami potencjalnej regulacji danego obszaru funkcjonowania społecznego,

- usprawnienie OSR poprzez włączenie jej na wczesnym etapie powstawania projektu aktu prawnego, szczególnie wobec podmiotów jego bezpośredniego i istotnego oddziaływania,

- popularyzacja wiedzy o metodyce OSR i jej potencjale w procesie stanowienia prawa,

- zacieśnienie współpracy z pracownikami naukowymi jako ważnymi podmiotami wsparcia procesu doskonalenia metodyki OSR,

- poszerzenie kręgu wykonawców OSR na kadrę akademicką, poza autorami propozycji legislacyjnych - kadry resortów, agencji opracowujących projekty,

- utworzenie bazy przykładów metod stosowanych w konkretnych przypadkach OSR, które miałyby służyć jako wzór i ułatwić pracę krajowych specjalistów OSR,

- uzupełnianie bazy formalnych wskazówek o praktycznym znaczeniu (możliwych do bezpośredniego wykorzystania przez autorów projektów) o kolejne elementy wypływające $\mathrm{z}$ doświadczenia wykonawców OSR oraz wzmocnienie ich rangi prawnej,

- uszczegółowienie wytycznych do wykonywania OSR właściwe dla poszczególnych resortów - dostosowanie zasad OSR do specyfiki przygotowywanych projektów aktów prawnych,

29 Na podstawie publikacji: Ocena Skutków Regulacji - poradnik OSR, doświadczenia, perspektywy, W. Szpringer, W. Rogowski (red.), Warszawa 2007.

30 Według obciążenia finansów publicznych, obciążenia wybranej grupy społecznej, potencjalnej kontrowersyjności społecznej czy poziomu zainteresowania i wrażliwości społecznej odnośnie do obszaru danej interwencji, poziomu kontrowersyjności, nieodwracalności i innowacyjności interwencji, wagi oczekiwanego wpływu, poziomu niepewności dotyczącej prawdopodobnego wpływu oraz dostępności czasu na opracowanie interwencji, BIS (Department for Business, Innovation and Skills), Impact assessment toolkit. How to do an Impact Assessment, London 2011, za: Ocena wplywu oparta na dowodach. Model dla Polski, J. Górniak (red.), Warszawa 2015, s. 180. 
- rozbudowanie OSR ex post, w tym przegląd istniejących regulacji pod kątem maksymalizowania ich użyteczności społecznej,

- silniejsze poparcie polityczne dla pełnego wdrażania reformy systemu oceny skutków regulacji,

- praca nad wyższym poziomem zaufania między administracją publiczną a partnerami społecznymi,

- niewystarczający poziom efektywności konsultacji społecznych (standardy konsultacji),

- niewystarczające analizy ryzyka wprowadzanych aktów prawnych,

- realna odpowiedzialność osób przygotowujących oceny wpływu.

Ujawniające się na bazie 162 prób badawczych efekty zastosowania OSR w Polsce w latach 2001-2005 nie pozwoliły wysunąć twierdzenia o ich pozytywnym wpływie na jakość stanowionego w kraju prawa. Rzetelne wdrażanie metodyki OSR (polecanej w dokumentach krajowych i zagranicznych - OECD, UE) było bardzo wyraźnie omijane w procesach legislacyjnych, szczególnie jeśli chodzi o wpływ regulacji bezpośrednio na przeciętnych obywateli kraju (w praktyce w analizach skupiano się na kontekście wpływu regulacji na finanse i podmioty publiczne). Jeśli podejmowano się opisu wpływu ingerencji władz publicznych, analiza dotyczyła głównie ogólnych korzyści podejmowanej regulacji ${ }^{31}$. Wiele aktywności legislacyjnych było pozbawionych procedury oceny skutków regulacji, obejmującej uzasadnienie potrzeby regulacji, określenie precyzyjnego celu regulacji, rozeznanie się w korzyściach i kosztach interwencji, rozpatrzenie wszystkich możliwych podejść do efektywnego rozwiązania problemu. Dodatkowo wyraźnie ujawniał się brak komunikacji z interesantami regulacji, ograniczona analiza kosztów i korzyści czy przewaga jakościowego ujęcia korzyści ${ }^{32}$.

Sporządzenie dokumentów „Opisy procedur przyjmowania projektów dokumentów rządowych” czy „Wytyczne do przeprowadzania oceny wpływu oraz konsultacji publicznych w ramach rządowego procesu legislacyjnego" z 2013 i 2014 r. ${ }^{33}$ pozwala stwierdzić, że służby administracji publicznej wykazywały pewne zainteresowanie rolą OSR, jak i procedurą ich wdrażania w wymaganych przypadkach. Podejmowano też próby pewnych reform $^{34}$. Mimo to dotychczasowa realizacja obowiązku OSR w Polsce oraz propozycje jej zmian są wielokrotnie ignorowane lub przeprowadzanie nie-

31 R. Zubek, Analiza polskiej praktyki oceny skutków regulacji w latach 2001-2005 [w:] Ocena Skutków Regulacji - poradnik OSR..., s. 43.

32 R. Zubek, Jak i dlaczego reformować ocenę skutków regulacji w Polsce?, opracowanie przygotowane na zlecenia Rzecznika Praw Obywatelskich, 26.01.2007, s. 7.

33 Opisy procedur przyjmowania projektów dokumentów rządowych; Wytyczne do przeprowadzania oceny wplywu oraz konsultacji publicznych $w$ ramach rządowego procesu legislacyjnego, http://www.rcl.gov.pl/book (dostęp: 20.09.2016).

34 Koncepcja usprawnienia konsultacji publicznych rządowych projektów aktów normatywnychorazocenyskutkówregulacji,https://www.ms.gov.pl/pl/archiwum-informacji/ news,4764,10,deregulacja-systemowa--koncepcja-reformy.html (dostęp: 20.01.2017). 
rzetelnie, co niejednokrotnie zwielokrotnia negatywne skutki. Wskazuje się na istnienie odwróconej piramidy stanowienia prawa ${ }^{35}$.

Kluczowe wydaje się zidentyfikowanie „wąskich gardeł” procesu oceny wpływu. Nieformalne rozmowy z pracownikami obecnego ośrodka koordynującego OSR prowadzą do wniosku o dewastującym proces ogniwie, jakim jest brak zasobów w postaci kapitału ludzkiego. Bezpośrednim tego efektem jest mierna koordynacja współpracy między urzędnikami administracji publicznej, pracownikami organizacji społecznych oraz akademikami.

\section{Zakończenie}

Zasadniczym celem przeprowadzania ocen wpływu regulacji jest neutralizowanie ryzyka pojawiającego się w efekcie wprowadzania rozwiązania drugiego po najlepszym - niezbędnej ingerencji publicznej w zachowania podmiotów gospodarczych. Szczególnie wrażliwe są obszary, na których regulacja generuje wysokie koszty finansowe, społeczne czy ekologiczne przy niewspółmiernie niskich korzyściach. W rezultacie regulacji ad hoc najczęściej pieniądze publiczne są marnotrawione, koszty transakcyjne podnoszone, a jakość usług publicznych obniżana. System gospodarczo-prawny narażany jest na zbędne turbulencje w postaci ciągłych poprawek złego prawa. Koszty regulacji narastają. Przedsiębiorcy ledwie nadążają za tempem zmian regulacyjnych, co często spycha ich w przestrzeń ignorancji prawnej, niepotrzebnego ryzyka czy wyższych kosztów transakcyjnych, w tym compliance cost. Ocena wpływu (ocena skutków regulacji) jako metoda analizy polityk publicznych i usprawnienia systemu tworzenia prawa ma dużą potencjalną wartość poznawczą i finansową.

Ocenę skutków regulacji można postrzegać jako pożądane narzędzie transformacji systemowej w świetle dojrzewania społecznej gospodarki rynkowej. Społeczna gospodarka rynkowa - ustrój gospodarczy oparty na konkurencji - stanowi jedną z propozycji ustrojowych ukazujących sposoby neutralizacji nieusuwalnego napięcia między wiedzą o efektywności ekonomicznej (ultraliberalizm) a poczuciem bezpieczeństwa socjalnego społeczeństwa (socjaldemokracja). Centralną ideą tego podejścia jest niweczenie wszelkich przejawów monopolizacji władzy we wszystkich obszarach funkcjonowania społeczeństwa, w tym szczególnie w gospodarce. Kluczową rolę do odegrania w realizacji tych celów ma proces stanowienia prawa. Prawo jest rudymentarnym elementem systemu gospodarczego opartego na konkurencji. Funkcjonalności temu systemowi nadają spraw-

35 Więcej: W. Rogowski, Skutki regulacji, czyli legislacja postawiona na głowie, Obserwatorfinansowy.pl. Ekonomia. Debata. Polska. Świat z 10.02.2011 r., https://www. obserwatorfinansowy.pl/forma/rotator/skutki-regulacji-czyli-legislacja-postawiona-na-glowie/ (dostęp: 20.12.2016). 
nie wdrażane mechanizmy stanowienia dobrego prawa w postaci takiej jak np. ocena skutków regulacji.

\section{Bibliografia}

Better regulation: making good use of regulatory impact assessment, National Audit Office, Report by the Comptroller and Auditor General HC 329 Session 2001-2002, London 2002.

BIS (Department for Business, Innovation and Skills), Impact assessment toolkit. How to do an impact assessment, London 2011.

Francesco F. de, Radaelli C.M., Troeger V.E., Implementing regulatory innovations in Europe: the case of impact assessment, "Journal of European Public Policy” 2011, DOI:10.1080/13501763.2011.607342.

Galbraith J.K., Godne społeczeństwo. Program troski o ludzkość, Warszawa 1999.

Jalilian H., Kirkpatrick C., Parker D., The impact of regulation on economic growth in developing countries: a cross-country analysis, „World Development” 2007, vol. 35 , iss. 1 .

Jørgensen T.B., Bozeman B., Public values: an inventory, „Administration and Society" 2007, vol. 39, no. 3.

Kirkpatrick C., Parker D., Regulatory impact assessment and regulatory governance in developing countries, "Public Administration and Development” 2004, vol. 24, no. 4.

Kirkpatrick C., Parker D., Regulatory Impact Assessment: an overview [w:] Regulatory Impact Assessment: towards better regulation, C. Kirkpatrick, D. Parker (eds.), The CRC Series on Competition, Regulation and Development, Edward Elgar Publishing 2007.

Knosala E., Zarys teorii decyzji w nauce administracji, Warszawa 2011.

Koncepcja usprawnienia konsultacji publicznych rządowych projektów aktów normatywnych oraz oceny skutków regulacji, https://www.ms.gov.pl/pl/archiwum-informacji/news,4764,10,deregulacja-systemowa--koncepcja-reformy.html.

McCubbins M.D., Noll R.G., Weingast B.R., Administrative procedures as instruments of political control, „Journal of Law, Economics, and Organization” 1987, vol. $3(2)$.

McCubbins M.D., Noll R.G., Weingast B.R., Structure and process, politics and policy: administrative arrangements and the political control of agencies, „Virginia Law Review" 1989, vol. 75 (2).

Nebel R., Regulations as a source of systemic risk: the need for economic impact analysis, „The Geneva Papers on Risk and Insurance” 2004, vol. 29, no. 2.

Ocena Skutków Regulacji - poradnik OSR, doświadczenia, perspektywy, W. Szpringer, W. Rogowski (red.), Warszawa 2007.

Ocena wplywu oparta na dowodach. Model dla Polski, J. Górniak (red.), Warszawa 2015.

Ocena Wpływu Regulacji. Poradnik dla administracji publicznej, Warszawa 2015.

Opisy procedur przyjmowania projektów dokumentów rzadowych oraz Wytyczne do przeprowadzania oceny wplywu oraz konsultacji publicznych $w$ ramach rzadowego procesu legislacyjnego, http://www.rcl.gov.pl/book. 
Osiecka-Chojnacka J., System oceny skutków regulacji w Polsce, „INFOS. Zagadnienia Społeczno-Gospodarcze" 2008, nr 2 (26).

Parker D., (Regulatory) impact assessment and better regulation [w:] D. Wright, P. de Hert, Privacy impact assessment, law, governance and technology, Series 2012, no. 6 .

Regulatory Impact Analysis, OECD resources: http://www.oecd.org/gov/regulatory-policy/ria.htm.

Regulatory Impact Analysis. Best practices in OECD countries, OECD, Paris 1997.

Renda A., Impact assessment in the EU: the state of the art and the art of the state, Brussels 2006.

Rogowski W., Skutki regulacji, czyli legislacja postawiona na głowie, Obserwatorfinansowy.pl. Ekonomia. Debata. Polska. Świat z dnia 10.02.2011, https://www. obserwatorfinansowy.pl/forma/rotator/skutki-regulacji-czyli-legislacja-postawiona-na-glowie/.

Stiglitz J.E., Ekonomia sektora publicznego, Warszawa 2015.

Stiglitz J.E., Freefall. Free markets and the sinking of the global economy, London 2010.

The OECD report on regulatory reform: synthesis, OECD Paris 1997.

Turnpenny J., Radaelli C.M., Jordan A., Jacob K., The policy and politics of policy appraisal: emerging trends and new directions, „Journal of European Public Policy" 2009, vol. 16 (4).

Zubek R., Jak i dlaczego reformować ocenę skutków regulacji w Polsce?, opracowanie przygotowane na zlecenia Rzecznika Praw Obywatelskich, 26.01.2007 r.

Streszczenie

Ważnym podejściem metodycznym do oceny regulacji jest ocena wpływu (ang. impact assessment), w polskim tłumaczeniu OSR (ocena skutków regulacji). Duży potencjał zabiegów związanych z OSR sprowadza się głównie do usprawnienia dialogu między organami publicznymi a interesariuszami, przygotowującego grunt pod wyższą jakość debaty, instytucji i - w efekcie - uchwalanego prawa. Zabiegi prowadzone w ramach OSR w celu neutralizowania negatywnych skutków działania mechanizmu rynkowego postrzegane są jednocześnie jako przejaw lepszego rządzenia (ang. better governance), nastawionego w szczególności na podniesienie poziomu inkluzyjności społecznej i obywatelskiej, a co za tym idzie efektywności regulacyjnej. Ocena skutków regulacji promuje szczególnie aspekt systemowości w stanowieniu prawa, a także podejście porównawcze w polityce decyzyjnej. Narzuca potrzebę wyraźnego wyodrębnienia problemu, który jest przedmiotem decyzji, szczegółowych celów politycznych, jakie mają być osiągnięte oraz zmusza do wskazania alternatywnych sposobów ich osiągania. Proces prowadzenia OSR w jurysdykcjach takich jak polska obnaża liczne słabe ogniwa tworzenia prawa oraz ukazuje głębokie braki infrastrukturalne w tym obszarze.

Słowa kluczowe: ocena skutków regulacji, niedoskonałości rynku, interes społeczny, wskazówki usprawniania systemu oceny wpływu 
Regulatory Impact Assessment as an Aspect of the Regulatory Process

Abstract

The chief method to weigh regulatory influence is Regulatory Impact Assessment (RIA). Its potential is hidden in the high probability of triggering the process of advancing dialogue between public representatives and stakeholders. That stimulates the creation of a fertile ground for the higher quality of public debate, institutions and, eventually, law. The RIA as a method of neutralising the negative consequences of the market mechanism is perceived as an expression of the better governance process focused on achieving more social inclusivity and higher regulatory effectiveness. The RIA promotes a systemic and comparison-friendly approach in the process of lawmaking. The RIA enforces the strict formulation of the problem (subject of regulation), aims of public intervention, and alternative ways of their attainment. The process of RIA in such jurisdictions as Polish still lags behind as a result of serious infrastructure shortages (human capital as a key one).

Keywords: Regulatory Impact Assessment, market imperfections, social interest, suggestions regarding improvements to impact assessment 